
3
Research Square
Preprints are preliminary reports that have not undergone peer review.
They should not be considered conclusive, used to inform clinical practice, or referenced by the media as validated information.

\title{
Taste and chemical composition as drives for utilitarian redundancy and equivalence: a case study in local medical systems in Northeastern Brazil
}

RAFAEL CORRÊA PROTA DOS SANTOS REINALDO

Universidade Federal Rural de Pernambuco

Flávia Rosa Santoro ( $\square$ flaviarsantoro@gmail.com )

UNC: Universidad Nacional de Cordoba https://orcid.org/0000-0002-1009-1941

ULYSSES PAULINO ALBUQUERQUE

Universidade Federal de Pernambuco

PATRÍCIA MUNIZ MEDEIROS

Universidade Federal de Alagoas

\section{Research Article}

Keywords: ethnobotany, organoleptic properties, selection criteria, traditional knowledge, use patterns

Posted Date: November 1st, 2021

DOl: https://doi.org/10.21203/rs.3.rs-900485/v1

License: (c) (i) This work is licensed under a Creative Commons Attribution 4.0 International License.

Read Full License

Version of Record: A version of this preprint was published at Journal of Ethnobiology and Ethnomedicine on January 25th, 2022. See the published version at https://doi.org/10.1186/s13002-02200503-1. 


\section{Abstract \\ Background}

We aimed to verify whether the taste and chemical composition influence the selection of plants in each medicinal category, whether within a socio-ecological system or between different socio-ecological systems. To this end, we use the theoretical bases of the Utilitarian Redundancy Model and the Utilitarian Equivalence Model. We studied the local medical systems of four rural communities in northeastern Brazil, used as models to test our assumptions.

\section{Methods}

The data on medicinal plants and local therapeutic function were obtained from semi-structured interviews associated with the free-listing method, allowing to generate indexes of similarity of therapeutic use between the plants cited in each region. During the interviews, each informer was also asked to report the tastes of the plants cited. Subsequently, we classified each plant in each region according to the most cited taste. The data about the chemical composition of each plant were obtained from a systematic review, using Web of Knowledge and Scopus databases.

\section{Results}

Pairs of plants with similar tastes are 1.46 times more likely to have the same therapeutic function within a local medical system (redundancy), but not between medical systems (equivalence). We also find that chemical compounds are not primarily responsible for utilitarian redundancy and equivalence. However, there was a tendency for alkaloids to be doubly present with greater expressiveness in pairs of equivalent plants.

\section{Conclusions}

The results indicate that each social group can create its means of using the organoleptic characteristics as clues to select new species as medicinal. Furthermore, this study corroborates the main prediction of the Utilitarian Equivalence Model, that people in different environments choose plants with traits in common for the same functions.

\section{Background}

The production of knowledge that constitutes local medical systems is influenced by several factors associated with human perception about the natural resources, such as its perceived availability and organoleptic properties, but also the intrinsic characteristics of the resources used, such as their chemical compounds $[1,2]$. Evidence in the literature shows that people from different regions of the world have 
similar patterns of use of medicinal plants [3], which may mean that these factors exert the same influence on different human populations, being responsible for the selection of medicinal species.

Among the organoleptic properties of medicinal plants, the taste has been mentioned in several studies as a clue to the inclusion of medicinal plants in local medical systems [4-14]. In general, these studies suggest that local populations use plant taste attributes to distinguish between medicinal and nonmedicinal plants, but few studies find a clear pattern on which tastes are attributed to which therapeutic functions. For example, in Patagonia Argentina, Morales and Ladio [14] reported that stomach problems are usually treated with sweet plants. On the other hand, in a municipality belonging to Chiapas, Mexico, Brett [5] found that the local population preferred plants with a sweet-smelling flavor to treat diseases related to the respiratory system, while the treatment of poisonous animals' bites was mostly conducted with the use of bitter plants. In other locations, bitter plants are used to treat gastrointestinal disorders such as diarrhea and dysentery $[12,13]$.

The chemical compounds may explain the importance of taste in selecting medicinal plants $[15,16]$. Terpenoids, flavonoids, tannins, and other chemical components that have pharmacological activity are usually related to the flavors presented in plants $[7,12]$. Nonetheless, different chemical compounds present the same taste [9] - mostly the bitter taste - and taste alone may not fully explain the selection of plants for different therapeutic functions. It is possible that chemical compounds are also responsible for the selection of medicinal plants by local populations, albeit indirectly - for example through the perception of effectiveness, as suggested by Medeiros et al. [1].

In this study, we seek to understand whether there is a pattern that relates taste and/or chemical compounds to specific medicinal functions within and between local medical systems. As mentioned, there are similar patterns of phylogenetic-based plant selection in different environments [3] (see also Reinaldo et al. [17]), but patterns that relate flavors and/or chemical composition to the same medicinal functions in different medical systems have not yet been seen.

If the taste and/or chemical composition of a plant influences in the same way the selection of medicinal plants by human groups, we would expect plants with the same taste and/or similar chemical composition to have the same medicinal function within and between cultural groups. In this sense, we can use two models that analyze the functions of medical systems: the Utilitarian Redundancy Model (URM) and the Utilitarian Equivalence Model (UEM) (box 1). Those models allow us to identify the influence of taste and chemical compounds in the selection of plants to each medical function within a medical system (URM) and between distinct medical systems, formed by people living in distinct cultural and environmental contexts (UEM).

Box 1: The Utilitarian Redundancy Model and the Utilitarian Equivalence Model 
Utilitarian Redundancy Model (URM): the URM derives from the ecological redundancy [18] by adopting a functional perspective in the analysis of natural resource use by human populations, and it evaluates the role of functional overlap within a socioecological system (see Albuquerque and Oliveira [19]). This analytical perspective arose from the observation that several species within a local medical system are used for the same therapeutic function - for example, mint and lemon can be both used to treat colds - they are culturally redundant regarding local use indications [20]. The model can be applied to any function of a socio-ecological system, not only medical ones. The URM model is based on the following assumptions: (a) species have different functions within socialecological systems, but a level of overlap in function (i.e., redundancy) occurs; (b) increased redundancy promotes resilience in social-ecological systems, and (c) redundancy depends on the knowledge characteristics and practices of a given human community [20]. For this study, we propose that redundant species in a medical system were selected for the same therapeutic function because they have a similar taste or chemical components.

Utilitarian Equivalence Model (UEM): The UEM is an operational concept based on Odum's [21] ecological equivalence model, which aims to understand the cases of overlapping of useful species in different socio-ecological systems [17]. Utilitarian equivalence, thus, indicates species that are used for the same purposes or similar purposes (not only medicinal ones) in different socioecological systems. Especially for medicinal use, equivalent species provides the ideal scenario to seek common selection criteria, in order to identify the shared characteristics among the equivalent pairs and consequently the main types of perceptions or stimuli, which led to the inclusion of such species in different local medical systems [17]. The model assumes that: (a) utilitarian equivalence, understood as the high overlap of use between two species in distinct socio-ecological systems, is relative and not absolute, since, in the absence of intrinsically identical plant species or culturally equal peoples, the medicinal uses are not necessarily identical, but rather similar; (b) equivalence is due to two groups of complementary variables, cultural traits and environmental factors; (c) the evolutionary events that led to utilitarian equivalence may be associated with the similarity between intrinsic characteristics of useful species. Thus, in this study we rely on one of the predictions of the UEM, that plants of distinct medical systems tend to share certain traits in common, such as taste and chemical compounds.

Following this rationale, we propose two hypotheses that try to understand the role of taste and chemical compounds on the selection of plants with therapeutic functions:

1. Species with similar tastes tend to present Utilitarian Redundancy and Utilitarian Equivalence. It is expected that, within a socio-ecological system, pairs of species that have similar tastes are more likely to have the same therapeutic function (redundancy) than pairs of species with different tastes. We also expect that, in distinct socio-ecological systems, pairs of species that have similar tastes are more likely to have the same therapeutic function (equivalence) than plants with different tastes

2. Species with similar chemical compounds tend to present Utilitarian Redundancy and Utilitarian Equivalence. It is expected that, within a socio-ecological system, pairs of species that have chemical compounds of the same class are more likely to have the same therapeutic function (redundancy) than pairs of species with chemical compounds of different classes. We also expect that, in distinct socio-ecological systems, pairs of species that have chemical compounds of the same class are more likely to have the same therapeutic function (equivalence) than plants with chemical compounds of different classes.

\section{Methods}

\subsection{Study area}


The study was conducted in four rural communities located in the Northeast of Brazil, two of them included in the Catimbau National Park (S 08\ 37'23"W37凶09'21"), a semi-arid region in the state of Pernambuco, and the other two included in the Murici Ecological Station (S 9凶 18'26"W35区 55'55"), a hot and humid climate region in the State of Alagoas. Communities were chosen based on their proximity and dependence on natural resources. In addition, we selected two regions of climate and water availability that were deeply different and with potentially different local floras because we intended to evaluate if under different socio-ecological conditional there is the same pattern of plant selection.

The Catimbau National Park has xerophytic vegetation locally known as caatinga. It is classified as a Seasonally Dry Tropical Forest (SDTF), with many deciduous, thorny, and succulent species. The cultural formation of local populations is marked by a strong influence of the Catholic and Protestant Christian religions. The communities studied were Igrejinha and Batinga, which are located in the region of the park belonging to the municipality of Buíque/PE, distant about $20 \mathrm{~km}$ from the urban area. The local climate is Bsh type, according to Köppen's classification [22] with rainfall regimes ranging from 650 to $1100 \mathrm{~mm}$, usually restricted from October to January. The community of Igrejinha has a population of 171 inhabitants while Batinga has 71 inhabitants. The medical service is offered by the municipality only in Vila do Catimbau, about ten kilometers from the communities. In addition, a Non-Governmental Organization (NGO) called Amigos do Bem ("Friends of the good") offers medical care and distribution of medicine to families in social vulnerability. Despite this, both communities have local plant-based medical systems, and the medicinal use of these resources is mainly made of teas and infusions.

The Murici Ecological Station, included in the municipality of Murici/AL, is covered by the Atlantic Rainforest. The Atlantic Rainforest, classified as Tropical Rainforest (TR), is considered one of the world's hotspots, with about 20 thousand species of vascular plants, of which $40 \%$ are endemic [23]. Its tropical hot-humid climate, type AS according to the classification of Koppen, is marked by rainfall ranging from 800 to $1800 \mathrm{~mm}$ and temperatures around $25^{\circ} \mathrm{C}$ [24]. The selected local communities were Settlement Che Guevara and Settlement Dom Helder Câmara, distancing about $13 \mathrm{Km}$ from the urban area. Both communities have as main activity family farming. A total of 204 people live in the settlement Dom Hélder Câmara, while the Settlement Che Guevara has 220 residents. Among the residents, prevail the Christian religious doctrines. The two communities have medical systems that are highly dependent on the use of plants, with a clear preference for these resources over biomedicine, for example. In both communities, there are common practices of magical-religious rituals from folk healers and holy women. Hospitals and health centers are restricted to the urban area, about $13 \mathrm{Km}$ away from the communities, and are often reached thanks to school buses from the municipality.

\subsection{Ethnobotanical Survey}

Most of the data were obtained from semi-structured interviews associated with the free-listing method and carried out with local specialists in medicinal plants, providing greater reliability of data on the repertoire of medicinal plants. This survey took place between January 2017 and January 2018 with monthly visits. We applied the snowball technique for the selection of experts [25]. In this technique, a first informant is asked to refer people in the community who have a piece of rich knowledge about the 
subject. Then, the referred ones, also refer to other informants. Only people over the age of 18 were included in the survey. In total, 127 people were interviewed, 49 from the TR areas and 88 from the SDTF area (see Table 01). In the interviews, the subjects were submitted to the following questions: 1) What medicinal plants do you know? 2) What is the use of each of these plants? 3) Does this plant have any taste? Which?

Table 1

Distribution of the interviewed local experts by community and by gender (sex).

\begin{tabular}{|lllll|}
\hline Ecosystem & Community & Men & Women & Total \\
\hline TR & Ass. D. Helder Câm & 15 & 11 & 26 \\
\hline SDTF & Ass. Che Guevara & 11 & 2 & 13 \\
\hline & Igrejinha & 26 & 34 & 59 \\
& Batinga & 13 & 16 & 29 \\
\hline & 65 & 63 & 127 \\
\hline
\end{tabular}

\subsection{Collection of botanical material and taxonomic identification}

The medicinal plants mentioned were collected in the region with the assistance of local experts. The identification of the species and the register of the testimonial material were carried out by the Instituto Agronômico de Pernambuco (IPA).

Regarding the collection of the above-mentioned plants, a request to carry out scientific research in the areas of the Catimbau National Park (PARNA Catimbau) and the Murici Ecological Station was made to ICMBio/SISBIO, an agency of the Brazilian Ministry of the Environment (MMA).

\subsection{Treatment of interview data}

The information collected from the informants was filtered by the inclusion and exclusion criteria described below.

\subsubsection{Preliminary screening of diseases and plant species: inclusion and exclusion criteria}

We considered only the diseases mentioned by two or more informants from a given region. Thus, if plant 'A' of the SDTF was only referred to 'influenza' and 'gastritis' uses and these data were mentioned by a single informant, those data were ignored, and consequently, plant A was excluded from the analyzes. Likewise, if in a given region none of the data on how to cure a particular disease was shared by two or more people, the disease was excluded from the analyzes. This process aimed to minimize the chances that idiosyncratic information would bias the findings. 


\subsubsection{Further screening of diseases and plant species: inclusion and exclusion criteria}

The current study falls into the etic approach, characterized by analyzing the phenomena from the researcher's perspective. Within this proposal, we consider only diseases and symptoms recognized by biomedicine. Some diseases considered in this study have a certain level of overlap with each other, such as diseases related to the respiratory system. However, in the local medical system, informants indicated that these were different things. In the case of expectorants, it was clear that they hoped the plant would help the body "throw it out". In contrast, when informants used plants to treat cough, the informants were aware that the goal was to stop the "spasms", which in turn would make expectorant action difficult. Following this distinction between citations of diseases and symptoms that fit or not for medical use from a biomedical viewpoint, only the diseases that occurred in both SDTF and TR were selected. There was also the exclusion of some species that treated only isolated diseases, occurring in only one of the regions.

\subsection{Obtaining the phytochemical data of the cited plants}

\subsubsection{Literature research strategy}

The database with the phytochemical profile of the plants included in the study comprised information on the presence or absence of the main classes of compounds, namely tannins, terpenes, alkaloids, flavonoids, and phenols. Data collection was based on information found in the available literature and recent research in the area. Pubmed, Scopus, and Web of Knowledge were consulted. The keywords used included the name of the respective species, "Species name + Ethnopharmacology", "Species name + chemical", "Species name + bioprospecting" and "specific name + Pharmacology". For each species, only studies analyzing at least one of the useful plant parts were considered.

We obtained 90 studies with information on 55 of the 64 selected medicinal species. However, to avoid bias, only studies that analyzed parts of the plants used by informants were considered. The papers found are shown in Table 2 and the phytochemical data extracted from them are included in Table 3. 
Table 2

List with the medicinal species considered in the study and the papers consulted.

\section{Plant Species}

Acanthospermum

hispidum DC.

Aloe vera (L.) Burm. f.

Amburana Cearensis

(Allemão) A.C.Sm.

Anacardium occidentale L.

Anadenanthera colubrina var. cebil (Griseb.) Altschul

Astraea lobata (L.)

Klotzsch

Bauhinia acuruana Moric. Trentin et al. [55]; Gois et al. [56]

Borreria verticillata (L.) G. Ushie et al. [57]; Baldé et al. [58]; Moreira et al. [59]

Mey.

Commiphora leptophloeos Clementino et al. [60]

(Mart.) J.B.Gillett

Copaifera lucens Dwyer

Cymbopogon citratus (DC) Geetha and Geetha[62]; Shah et al. [63]; Cheel et al. [64] Stapf.

Dysphania ambrosioides

(L.) Mosyakin and

Clemants

Genipa americana L.

Handroantus

impetiginosus (Mart.ex

DC.) Mattos

Hymenaea courbaril L.

Jatropha gossypiifolia L.

Libidibia ferrea (Mart. Ex

Tul.) L.P.Queiroz

Lippia origanoides Kunth

Mentha piperita L.

Comandolli-Wyrepkowski et al. [75]
Santos et al. [61]

Chika et al. [26]; Sanon et al. [27]; N'do et al. [28]; Tirloni et al. [29];

Ganfon et al. [30]; Arena et al. [31]; Roy et al. [32]

Benzidia et al.[33]; Kumar et al.[34]; Cock [35]; Guo and Mei [36]; Salehi et al. [37]; Taukoorah and Mahomoodally [38]; Mariita et al.[39]

Costa et al. [40]; Canuto and Silveira [41]; Leal et al. [42]; Costa-Lotufo et al. [40]; Farias et al. [43]

Mustapha et al. [44]; Tedong et al. [45]; Carvalho et al. [46]; Souza et al. [47]

Lima Neto et al. [48]; Vigerelli et al. [49]; Cartaxo et al. [50]; Gutierrez-

Lugo et al. [51]; Melo et al. [52]; Damascena et al. [53]

Ezeabara and Okonkwo [54]

Loufoua et al. [65]; Zohra et al. [66]; Soares et al. [67]; Mwanauta et al. [68]

Barbosa et al. [69]; Soares et al. [67]

Pires et al. [70]

Bezerra et al. [71]; Cecílio et al. [72]; Aleixo et al. [73]

Félix-Silva et al. [74]

Pinto et al. [76]

Ramkissoon et al. [77]; Zheljazkov and Astatkie [78] 


\begin{tabular}{|c|c|}
\hline Plant Species & References \\
\hline $\begin{array}{l}\text { Mimosa tenuiflora (Willd.) } \\
\text { Poir. }\end{array}$ & Bezerra et al. [71] \\
\hline $\begin{array}{l}\text { Myracrodruon urundeuva } \\
\text { Allemão }\end{array}$ & Cecílio et al. [72] \\
\hline Ocimum gratissimum $\mathrm{L}$. & Kpadonou-Kpoviessi et al. [79]; Aba and Udechukwu [80] \\
\hline Passiflora cincinnata Mast. & Siebra et al. [81] \\
\hline Passiflora foetida L. & Patil and Paikrao [82] \\
\hline Phyllanthus urinaria L. & Xu et al. [83]; Chung et al. [84] \\
\hline $\begin{array}{l}\text { Plinia cauliflora (Mart.) } \\
\text { Kausel }\end{array}$ & Chavasco et al. [85]; Oliveira et al. [86] \\
\hline Psidium guajava L. & Cecílio et al. [72]; Morais-Braga et al. [87] \\
\hline Psidium guineense $\mathrm{Sw}$. & González et al. [88] \\
\hline Punica granatum L. & Rajeswari [89]; Calín-Sánchez et al. [90] \\
\hline Rosmarinus officinalis L. & Btissam et al. [91]; Pérez-Mendoza et al. [92] \\
\hline Ruta graveolens L. & Amabye and Shalkh [93]; Sampaio et al. [94] \\
\hline Sambucus nigra L. & Akhtar et al. [95] \\
\hline $\begin{array}{l}\text { Schinopsis brasiliensis } \\
\text { Engl. }\end{array}$ & Lima-Saraiva [96]; Barbosa et al. [69] \\
\hline $\begin{array}{l}\text { Schinus terebinthifolia var. } \\
\text { acutifolia Engl. }\end{array}$ & Abdul-Hafeez et al. [97] \\
\hline Solanum paniculatum $\mathrm{L}$. & Lôbo et al. [98] \\
\hline $\begin{array}{l}\text { Syzygium cumini (L.) } \\
\text { Skeels }\end{array}$ & Akhtar et al. [95]; Tripathi and Kohli [99] \\
\hline $\begin{array}{l}\text { Vismia guianensis (Aubl.) } \\
\text { Choisy }\end{array}$ & Camelo et al. [100] \\
\hline Ximenia americana linn & Gaichu et al. [101]; Aragão et al. [102]. \\
\hline Ziziphus joazeiro Mart. & Brito et al. [103]; Andrade et al. [104] \\
\hline
\end{tabular}

\subsection{Data analysis}

The indication of species equivalent and redundant between and for the SDTF and TR areas was performed through a similarity analysis (Jaccard). A binary matrix containing the information obtained from the informants was created, with plant species as objects and diseases as descriptors. Whenever a species was used for a given disease, the cell was filled with a value of 1 . When a species was not used 
for a given disease, the cell in question was zero. The analyzes did not include doubles of the same species.

In cases where the same species was mentioned in both regions, it entered the matrix as two distinct entities (Plant A - TR and Plant A - SDTF). From the binary matrix, the Jaccard similarity matrix was constructed. Doubles of species with more than $50 \%$ use overlap were considered 'redundant' (when dealing with plants from the same region) and 'equivalent' (when dealing with plants from different regions). To determine in which categories of flavor the plant species would be categorized, each plant in each region was classified according to the flavor and most cited. The flavor and level of availability considered for each plant are shown in Table 3.

For the analysis of the influence of taste and chemical composition of the establishment of utilitarian equivalence and utilitarian redundancy among plant species, the odds ratio (OR) test was used, which is more appropriate to analyze small values once that the number of equivalent pairs was much smaller than the number of pairs that were not equivalent. This test verified: 1 ) if pairs formed by plants containing a given taste are more likely to be redundant; 2 ) if pairs formed by plants containing a given class of chemical compounds are more likely to be redundant; 3 ) if pairs formed by plants containing a given taste are more likely to be equivalent; 4 ) if pairs formed by plants containing a given class of chemical compound are more likely to be equivalent. These tests were performed for terpenes, alkaloids, phenolic compounds, tannins, and flavonoids.

The $p$ value for each test was calculated by testing the null hypothesis of independence between the variables. The odds ratio calculations were performed by the oddsratio function of the fmsb package of the statistical program R, version 3.2.2 (The R Foundation for Statistical Computing). For the processed tests, $p<0.05$ was allowed.

\section{Results}

Gathering the selected data, we had 27 diseases and 64 plant species, with seven of the cited species occurring in both SDTF and TR. However, only the 48 plants identified up to the species level and with phytochemical studies were included in the analyzes.

In the fifth column are the classes of compounds attributed to the cited plants, namely Alkaloids (ALK), Phenols (PHE), Flavonoids (FLA), Tannins (TAN) and Terpenes (TER). In the sixth column, SDTF indicates that the species in question was obtained in the Seasonally Dry Tropical Forest, while TR indicates that the species was obtained in the Tropical Rainforest. Cells containing NA, mean that this information does not apply to the analyzes or that this data was not obtained.

We observed that pairs with the same taste are 1.46 times more likely to be redundant than different taste pairs $(O R=1.46, I C=0.99-2.14, p=0.05)$. Several reports and citations recorded in the interviews on the taste of the species also allow inferring that in the communities studied, the taste is used as a trail of therapeutic efficacy. When asked about the taste of Mesosphaerum pectinatum (L.) Kuntze, a species 
used as an analgesic, a 66-year-old informant living in the community of Dom Helder Câmara states that "for pain, the bitter the better ... nothing that is sweet suits". On another occasion, also in this community, a 61 years old informant emphasized that "For the flu, the remedy has to be bitter ... can not suck sugarcane or eat couscous", referring to the bitter taste of the species Solanum paniculatum $\mathrm{L}$.

Based on the informants' comments, including those mentioned above, there also seems to be a consensus that the bitter taste signals medicinal value. The relationship between the unpleasant taste, usually bitter, and perceived therapeutic efficacy have also been registered, as follows: "the healing remedy is bad to take! not good, no! "- Informant from Dom Helder Câmara community, 75 years.

In another community, people have shown caution regarding the use of bitter plants. This is clear in practically all the interviews, as one can note in the following comment: "if you drink too much of this tea it is intoxicating because it is very bitter" - Informant of the Batinga community, 27 years old. Something also common in the informants' speech was the relationship between plant bitterness and abortifacient properties, and it is common to hear comments such as "pregnant women cannot take mororó (Bauhinia acuruana Moric.) because it is bitter" - Informant from the Batinga community, 41 years old.

Concerning the chemical compounds, there was no positive correlation between the pairs that had a given class of compound and the establishment of redundancy, as can be observed in the results for alkaloids ( $O R=1.07, I C=0.51-2.24, p=0.8659)$, tannins $(O R=1.3, I C=0.48-3.50, p=0.606)$, flavonoids $(\mathrm{OR}=2.56, \mathrm{IC}=0.60-10.90, \mathrm{p}=0.1891)$ and terpenes $(\mathrm{OR}=1.56, \mathrm{IC}=0.53-4.53, \mathrm{p}=0.4144)$. Furthermore, contrary to what we expected, there is less chance of pairs that share phenols being redundant than pairs that don't $(\mathrm{OR}=0.27, \mathrm{IC}=0.12-0.61, \mathrm{p}=0.0008319)$.

The analysis showed that in the scenario investigated there is no relation between the taste attributed to a plant and the Utilitarian Equivalence, $(\mathrm{OR}=1.08, \mathrm{IC}=0.71-1.66, \mathrm{p}=0.70)$. The analyses also indicate that, in general, the classes of compounds studied do not affect Utilitarian Equivalence, as shown by the results for the flavonoids ( $O R=1.84, I C=0.55-6.22, p=0.318)$, Phenols $(O R=0.72, I C=0.26-1.96, p=0.5139)$, tannins $(\mathrm{OR}=2.21, \mathrm{IC}=0.65-7.63 ; \mathrm{p}=0.193)$, and terpenes $(\mathrm{OR}=1.08, \mathrm{IC}=0.37-3.21, \mathrm{p}=0.8849)$. Regarding alkaloids, the figures associated with the influence on equivalence were not significant as well but were very close to that $(\mathrm{OR}=2.21, \mathrm{IC}=0.96-5.12 ; \mathrm{p}=0.057)$. Thus, in the specific case of alkaloids, there may be a relationship.

\section{Discussion}

4.1 There is more chance of occurrence of Utilitarian Redundancy among species with similar tastes. The same does not occur with Utilitarian Equivalence.

The fact that taste does not contribute to the establishment of utilitarian equivalence, but favors the establishment of utilitarian redundancy, may indicate that the cultural factor on the perception of taste predominates over any biological factor, intrinsic to any person in any social group. That is, the perception that something is good for $x$ disease because it is "bitter" or "astringent" is influenced by the 
cultural context in which they are inserted. In another location, a person may perceive the same taste, but not attribute it to an $x$ disease.

Our data on the relationship of taste with redundancy seems to support the findings of other studies elsewhere in the world. As previously mentioned, it seems that in different places around the world, tastes are used to identify different medicinal functions. For example, bitter tasting plants are indicated for the treatment of inflammation in some places [13] and for gastrointestinal disorders in other places [12].

Based on the comments made by informants from the communities studied in TR and SDTF regions, we can see that the same bitter taste has different interpretations. For example, we found comments related to bitter taste as something toxic and abortive, in SDTF region, while in TR region, people say that that any good medicine has to be bitter, such as the statements made by two informants of Ass. D. Helder Câmara, "healing remedy is bad to take! not good", and "for pain, the bitter the better ... nothing that is sweet suits". These citations probably correspond to behaviors that, based on previous positive experiences involving the use of bitter-tasting medicinal plants, may guide future episodes of plant selection for these same therapeutic purposes. This is perhaps the main selection mechanism involving taste.

A point to be discussed about our results is the influence of environmental aspects of each region on the production of bioactive compounds and, consequently, on the taste used as a clue. Studies have shown that biochemical routes benefit certain compounds in SDTF and others in TR. In the case of the TR, there are indications that environmental conditions favor biochemical routes related to alkaloid production [105] whereas in SDTF biochemical routes seem to benefit the production of phenolic compounds [105]. Therefore, learning events from the experimentation of floras from distinct environments may make it possible that the compound, and consequently, the taste that treats a particular disease in the SDTF to be different from that used in the TR.

The taste proved to be important for the selection of medicinal plants. People in distinct places consider the taste when choosing their plants. However, depending on the cultural and environmental issues of each local population, the same taste can be attributed to different functions. This shows that there is indeed a trail of chemical efficacy [1] that gradually makes people relate certain tastes to certain diseases in each cultural and environmental context in which they operate [1].

Although it is clear that taste serves as a trail for therapeutic efficacy, the findings that a taste corresponds to a therapeutic activity (through trial and error) are closely related to the chemical repertoire of the local flora. In the case of, for example, a much larger spectrum of phenolic compounds over others, local knowledge on taste versus therapeutic activity may reflect this particularity. In other words, under a parsimonious look, the relationship between taste and medicinal use will always depend on a chemical repertoire available, [2].

\subsection{In general, it is not the classes of compounds that determine the Utilitarian Redundancy and Utilitarian Equivalence.}

Page $12 / 24$ 
The mere presence of a class of compounds is not decisive for the occurrence of utilitarian redundancy and equivalence. But in the specific case of alkaloids, it might be relatable that pairs of species with the same class of chemical compounds are equivalentes, because of the confidence interval that is almost 1. The result for this class of compound is quite different from those observed for the other ones. The data indicate a tendency for alkaloids to be present twice as expressively in equivalent plant pairs.

Based on the assumption that a large part of the secondary metabolites is intended to inhibit herbivory [106], it is believed that classes of low molecular weight compounds, such as alkaloids, can present bioactivity, even though they occur at low concentrations. In contrast, high molecular weight secondary metabolites, such as tannins, require high concentrations for biological activity to be satisfactory [106, 107]. As the present study used information from studies that aimed at determining the presence or absence of classes of compounds, the data presented here do not capture this flexible and dependent nature of plant concentrations. These are necessary to allow the existence of a pharmacological activity capable of sustaining the therapeutic use of a given plant species in a local community. Conversely, we can infer that the likely positive relation between Utilitarian Equivalence and the double presence of alkaloids may be related to the high bioactivity of these compounds, albeit in low concentrations.

As already discussed, an important aspect of the results is the influence of abiotic conditions on the production of secondary metabolites [108]. The present study reflects the use of plants occurring in semiarid and humid areas. It is likely that the difference in environmental conditions is influencing the production of medicinal value compounds and, considering that there were species in both SDTF and TR with different uses, these may not meet the same therapeutic demands due to environmental influences. In this sense, there is evidence that factors such as seasonality, temperature, water availability, ultraviolet radiation; nutrient availability, and altitude may alter the amount and types of plant chemical constituents [108]. For example, a positive relationship between tannin production and environmental conditions has been found in the semi-arid region of Northeast Brazil [109-111]. Thus, from the ecological point of view, SDTF plants would have more conditions to produce tannins than TR plants.

Another point that deserves discussing is the possibility that different classes of compounds may promote similar biological activities. Thus, it may be that two plants are used to treat a certain disease, but distinct compounds, not shared between plants, are responsible for the combined therapeutic activity. Following this reasoning, if species treat general illnesses, then pairs of equivalent plants would not necessarily need to have the same class of compound because other classes of compounds act similarly to cure this disease range.

In addition to these elements of ecological influence, many local communities, inhabiting mainly dry forests, have developed strategies for medicinal use that are different from those used by communities that inhabit humid forests [112]. Due to the semi-arid regime and the scarcity of leaves and fruits during most of the year, the behavior of prioritizing the use of tree barks to the detriment of other parts was developed [112]. Although they share chemical compounds, bark and leaves often have distinct concentrations of the same compounds [113]. As a result, tree species that have a low concentration of a 
given bioactive compound in the bark and a higher concentration in the leaves may not present satisfactory results for the treatment of certain diseases depending on the way they are used by SDTF populations. Thus, double presence alone would not be enough to guarantee Utilitarian Equivalence, especially for high molecular weight compounds such as tannins $[106,107]$.

It is important to point out that other factors can act together with bioactive compounds and/or with organoleptic characteristics, influencing the healing process and the behavior of the use of medicinal resources [114]. According to Moerman and Jonas [115], there is a meaning response effect, whose healing effect is due more to psychological circumstances than to the existence of bioactive compounds in a resource [115]. When the cure from a given treatment is taken for granted, an immune response occurs, expanding the efforts and thus the energy used by the human organism to treat a disease [116]. Following this perspective, the use of bitter-tasting plants in a cultural context that considers this organoleptic characteristic to be effective in treating diseases can favor the success of the treatment. In this scenario, the habit of using medicinal plants with a bitter taste could be considered an adaptive behavior and thus would tend to settle in the local culture. Therefore, the meaning response can partly explain the existence of usage patterns of plants.

\subsection{Limitations}

From a methodological viewpoint, this study has some limitations. The first issue concerns collection of taste data. Although the organoleptic property examined in this study was the taste, some people may mix taste and smell into a somehow blurred category. In this sense, some informants spontaneously mentioned the strong smell of some plants, such as mint. However, the information obtained does not allow us to infer the relevance of these characteristics in the local context and we decided not to explain the role of smell in the studied medical system. We relied only on the answers that the informants mentioned the taste, according to their perception of what is taste. Besides that, we accessed the flavor by resorting to people's memories, not by having them taste the plants at the time of the interview. Given the inherent mnemonic limitations of humans, there is a high probability that some flavor has been forgotten.

The second question is about the chemical classification adopted: tannins, phenolics, alkaloids, terpenes, and flavonoids. Initially, the goal was to divide terpenes into small terpenes and large ones, as far as they have very distinct pharmacological properties. However, we found a very small amount of phytochemical studies for these subclasses of compounds, which made it impossible to perform statistical analyzes. It can also be that the absence of findings concerning chemical classes reflects the small size of your sample and our wide chemical classifications. Thus, as this is a first theoretical approach, we find it reasonable to conduct a study that considers the large classes of compounds.

\section{Conclusion}


Taste is an important clue in the selection of medicinal plants by local populations. However, based in our results this clue operates in a different way depending on the cultural and environmental aspects of each local population. It means that, although populations take taste into account in order to include a medicinal plant in their medical system, different factors cause a taste to be attributed to a particular therapeutic function. Plants with the same taste tend to have the same function within but not between local medical systems.

Our results do not allow us to say that the class of plants chemical compounds influences the selection of medicinal plants for the therapeutic categories. However, the suposed influence of the presence of alkaloids for the establishment of Utilitarian Equivalence meke us suspect that the chemical composition of plants can contribute to the establishment of certain patterns of use of plants. At this point, we emphasize that the data on the chemical repertoire of plants were limited to presence or absence and were obtained from the available scientific literature. Consequently, it was not possible to know the actual tissue concentration of the compounds in the plants used in situ, which we considered a limitation of our results.

The empirical data of the present study corroborate the main prediction of the Utilitarian Equivalence Model, that plants of distinct medical systems tend to share certain traits in common.

\section{Abbreviations}

URM - Utilitarian Redundancy Model

UEM - Utilitarian Equivalence Model

SDTF - Seasonally Dry Tropical Forest

TR - Tropical Rainforest

\section{Declarations}

\section{Ethics approval and consent to participate}

The present study obtained authorization from the Human Research Ethics Committee, number 30919514.9.0000.5207, following the provisions of resolution 466/2012 of the National Health Council in Brazil. In addition, all informants signed the informed consent form prior to their participation.

\section{Consent for publication}

Not applicable

\section{Availability of data and materials}

All data generated or analysed during this study are included in this published article 


\section{Competing interests}

The authors declare that they have no competing interests

\section{Funding}

National Council for Scientific and Technological Development - CNPq granted a scholarship to RCPSR.

\section{Authors' contributions}

RCPSR collected data, RCPSR, PMM, UPA and FRS analyzed, interpreted data and wrote the manuscript. All authors read and approved the final manuscript.

\section{Acknowledgements}

We wish to thank the communities Igrejinha, Batinga, Assentamento Dom Helder Câmara, and Assentamento Che Guevara, for the extraordinary receptivity which allowed the obtainment of the necessary data, Denis Linhares Corrêa (in memorian) for collaborating with the construction of the data bank used in the present study.

\section{References}

1. Medeiros PM, Ladio AH, de Albuquerque UP. Local Criteria for Medicinal Plant Selection. In: Albuquerque UP, De Medeiros PM, Casas A, editors. Evolutionary Ethnobiology. Cham: Springer International Publishing; 2015. p. 149-62.

2. Silva FG, Oliveira CBA, Pinto JEBP, Nascimento VE, Santos SC, Seraphind JC, et al. Seasonal variability in the essential oils of wild and cultivated Baccharis trimera. J Braz Chem Soc. 2007;18:990-7.

3. Saslis-Lagoudakis CH, Savolainen V, Williamson EM, Forest F, Wagstaff SJ, Baral SR, et al. Phylogenies reveal predictive power of traditional,medicinein bioprospecting. Proc Natl Acad Sci U S A. 2012;109:15835-40.

4. Ankli A, Sticher O, Heinrich M. Yucatec Maya medicinal plants versus nonmedicinal plants: Indigenous characterization and selection. Hum Ecol. 1999;27:557-80.

5. Brett JA. Medicinal plant selection criteria: The cultural interpretation of chemical senses. J Appl Bot. 1998;72:70-4.

6. Leonti M, Sticher O, Heinrich M. Medicinal plants of the Popoluca, México: Organoleptic properties as indigenous selection criteria. J Ethnopharmacol. 2002;81:307-15.

7. Brett JA, Heinrich M. Culture, perception and the environment: The role of chemosensory perception. J Appl Bot. 1998;72:67-9.

8. Casagrande D. Human Taste and Cognition in Tzeltal Maya Medicinal Plant Use. J Ecol Anthropol. 2000;4:57-69. 
9. Dragos D, Gilca M. Taste of phytocompounds: A better predictor for ethnopharmacological activities of medicinal plants than the phytochemical class? J Ethnopharmacol. 2018;220:129-46.

10. Geck MS, Cabras S, Casu L, Reyes García AJ, Leonti M. The taste of heat: How humoral qualities act as a cultural filter for chemosensory properties guiding herbal medicine. J Ethnopharmacol. 2017;198:499-515.

11. Gilca M, Barbulescu A. Taste of medicinal plants: A potential tool in predicting ethnopharmacological activities? J Ethnopharmacol. 2015;174:464-73.

12. Heinrich $M$, Rimpler $H$, Barrera NA. Indigenous phytotherapy of gastrointestinal disorders in a lowland Mixe community (Oaxaca, Mexico): Ethnopharmacologic evaluation. J Ethnopharmacol. 1992;36:63-80.

13. Medeiros PM, Santos Pinto BL, Do Nascimento VT. Can organoleptic properties explain the differential use of medicinal plants? Evidence from Northeastern Brazil. J Ethnopharmacol. 2015;159:43-8.

14. Molares S, Ladio A. Plantas medicinales en una comunidad Mapuche del NO de la Patagonia Argentina: clasificación y percepciones organolépticas relacionadas con su valoración. Boletín Latinoam y del Caribe Plantas Med y aromáticas. 2008;7:149-55.

15. Behrens M, Brockhoff A, Batram C, Kuhn C, Appendino G, Meyerhof W. The human bitter taste receptor hTAS2R50 is activated by the two natural bitter terpenoids andrographolide and amarogentin. J Agric Food Chem. 2009;57:9860-6.

16. Drewnowski A, Gomez-Carneros C. Bitter taste, phytonutrients, and the consumer: A review. American Journal of Clinical Nutrition. 2000;72:1424-35.

17. Reinaldo R, Albuquerque U, Medeiros P. Taxonomic affiliation influences the selection of medicinal plants among people from semi-arid and humid regions - A proposition for the evaluation of utilitarian equivalence in Northeast Brazil. PeerJ. 2020;8:e9664.

18. WALKER BH. Biodiversity and Ecological Redundancy. Conserv Biol. 1992;6:18-23.

19. Albuquerque UP de, Oliveira RF de. Is the use-impact on native caatinga species in Brazil reduced by the high species richness of medicinal plants? J Ethnopharmacol. 2007;113:156-70.

20. Nascimento ALB, Júnior WSF, Ramos MA, de Medeiros PM, Soldati GT, Santoro FR, et al. Utilitarian Redundancy: Conceptualization and Potential Applications in Ethnobiological Research. In: Evolutionary Ethnobiology. Cham: Springer International Publishing; 2015. p. 121-30.

21. Odum E. Fundamental of Ecology. Third. Philadelphia: W.B. Saunders Co; 1971.

22. Alvares CA, Stape JL, Sentelhas PC, De Moraes Gonçalves JL, Sparovek G. Köppen's climate classification map for Brazil. Meteorol Zeitschrift. 2013;22:711-28.

23. Sobral M, Stehmann JR. An analysis of new angiosperm species discoveries in Brazil (1990-2006). In: Taxon. International Association for Plant Taxonomy; 2009. p. 227-32.

24. IBAMA. Plano Operativo de Prevenção e Combate aos incêndios florestais na estação Ecológica Murici. MMA. 2006;:15. 
25. Bailey K. Methods of Social Research. 4th edition. New York, NY: The Free Press; 2008.

26. Chika A, Onyebueke DC, Bello SO. Phytochemical analysis and evaluation of antidiabetic in alloxaninduced diabetic rats treated with aqueou se flfeeactf s extract of Acanthospermum hispidum. African J Biomed Res. 2018;21:81-5.

27. Sanon S, Azas N, Gasquet M, Ollivier E, Mahiou V, Barro N, et al. Antiplasmodial activity of alkaloid extracts from Pavetta crassipes (K. Schum) and Acanthospermum hispidum (DC), two plants used in traditional medicine in Burkina Faso. Parasitol Res. 2003;90:314-7.

28. N'DO J, HILOU A, OUEDRAOGO N, SOMBIE E, TRAORE T. Phytochemistry, Antioxidant, and Hepatoprotective Potential of Acanthospermum hispidum DC Extracts against DiethylnitrosamineInduced Hepatotoxicity in Rats. Medicines. 2018;5:42.

29. Tirloni CAS, Lívero FA dos R, Palozi RAC, Silveira RCA, Vasconcelos PC de P, Souza RIC, et al. Ethnopharmacological investigations of the cardio-renal properties of a native species from the region of Pantanal, state of Mato Grosso do Sul, Brazil. J Ethnopharmacol. 2017;206:125-34.

30. Ganfon H, Bero J, Tchinda AT, Gbaguidi F, Gbenou J, Moudachirou M, et al. Antiparasitic activities of two sesquiterpenic lactones isolated from Acanthospermum hispidum D.C. J Ethnopharmacol. 2012;141:411-7.

31. Arena ME, Cartagena E, Gobbato N, Baigori M, Valdez JC, Bardon A. In vivo and in vitro antibacterial activity of acanthospermal $B$, a sesquiterpene lactone isolated from Acanthospermum hispidum. Phyther Res. 2011;25:597-602.

32. Roy H, Chakraborty A, Bhanja S, Shankar Nayak Sruti Ranjan Mishra B, Ellaiah P. Preliminary phytochemical investigation and anthelmintic activity of Acanthospermum hispidum DC.

33. Benzidia B, Barbouchi M, Hammouch H, Belahbib N, Zouarhi M, Erramli $H$, et al. Chemical composition and antioxidant activity of tannins extract from green rind of Aloe vera (L.) Burm. F. J King Saud Univ - Sci. 2019;31:1175-81.

34. Kumar S, Yadav A, Yadav M, Yadav JP. Effect of climate change on phytochemical diversity, total phenolic content and in vitro antioxidant activity of Aloe vera (L.) Burm.f. BMC Res Notes. 2017;10:60.

35. Cock IE. The genus aloe: Phytochemistry and therapeutic uses including treatments for gastrointestinal conditions and chronic inflammation. Prog Drug Res. 2015;70:179-235.

36. Guo X, Mei N. Aloe vera: A review of toxicity and adverse clinical effects. J Environ Sci Heal - Part C Environ Carcinog Ecotoxicol Rev. 2016;34:77-96.

37. Salehi B, Jornet PL, López EPF, Calina D, Sharifi-Rad M, Ramírez-Alarcón K, et al. Plant-derived bioactives in oral mucosal lesions: A key emphasis to Curcumin, Lycopene, chamomile, aloe Vera, green tea and coffee properties. Biomolecules. 2019;9:106.

38. Taukoorah U, Mahomoodally MF. Crude Aloe vera Gel Shows Antioxidant Propensities and Inhibits Pancreatic Lipase and Glucose Movement in Vitro. Adv Pharmacol Sci. 2016;2016.

39. Mariita R, Okemo P, Kirimuhuzya C, Otieno J, Magadula J, Orodho J. Methanolic extracts of Aloe secundiflora Engl. inhibits in vitro growth of tuberculosis and diarrhea-causing bacteria. 
Pharmacognosy Res. 2011;3:95.

40. Costa-Lotufo L V., Jimenez PC, Wilke D V., Leal LKAM, Cunha GMA, Silveira ER, et al. Antiproliferative Effects of Several Compounds Isolated from Amburana cearensis A. C. Smith. Zeitschrift fur Naturforsch - Sect C J Biosci. 2003;58:675-80.

41. Canuto KM, Silveira ER. Chemical constituents of trunk bark of Amburana cearensis A.C. Smith. Quim Nova. 2006;29:1241-3.

42. Leal LKAM, Fonseca FN, Pereira FA, Canuto KM, Felipe CFB, Fontenele JB, et al. Protective effects of amburoside A, a phenol glucoside from Amburana cearensis, against CCl4-induced hepatotoxicity in rats. Planta Med. 2008;74:497-502.

43. Farias DF, Cavalheiro MG, Viana MP, Queiroz VA, Rocha-Bezerra LCB, Vasconcelos IM, et al. Water extracts of Brazilian leguminous seeds as rich sources of larvicidal compounds against Aedes aegypti L. An Acad Bras Cienc. 2010;82:585-94.

44. Mustapha AA, Owuna G, Ogaji JO, Is-Haq Is-Haq U, Idris MM. Phytochemical screening and inhibitory activities of anacardium occidentale leave extracts against some clinically important bacterial isolates. Int J Pharmacogn Phytochem Res. 2015;7:365-9.

45. Tédong L, Dzeufiet PDD, Dimo T, Asongalem EA, Sokeng SN, Flejou JF, et al. Acute and subchronic toxicity of Anacardium occidentale Linn (Anacardiaceae) leaves hexane extract in mice. African J Tradit Complement Altern Med. 2007;4:140-7.

46. Carvalho GHF, de Andrade MA, de Araújo CN, Santos ML, de Castro NA, Charneau S, et al. Larvicidal and pupicidal activities of eco-friendly phenolic lipid products from Anacardium occidentale nutshell against arbovirus vectors. Environ Sci Pollut Res. 2019;26:5514-23.

47. Souza MQ, Teotônio IMSN, de Almeida FC, Heyn GS, Alves PS, Romeiro LAS, et al. Molecular evaluation of anti-inflammatory activity of phenolic lipid extracted from cashew nut shell liquid (CNSL). BMC Complement Altern Med. 2018;18.

48. Lima Neto GA, Kaffashi S, Luiz WT, Ferreira WR, Dias Da Silva YSA, Pazin G V., et al. Quantificação de metabólitos secundários e avaliação da atividade antimicrobiana e antioxidante de algumas plantas selecionadas do Cerrado de Mato Grosso. Rev Bras Plantas Med. 2015;17:1069-77.

49. Vigerelli H, Sciani J, Jared C, Antoniazzi M, Caporale GM, da Silva A de CR, et al. Bufotenine is able to block rabies virus infection in BHK-21 cells. J Venom Anim Toxins Incl Trop Dis. 2014;20:45.

50. Cartaxo SL, de Almeida Souza MM, de Albuquerque UP. Medicinal plants with bioprospecting potential used in semi-arid northeastern Brazil. J Ethnopharmacol. 2010;131:326-42.

51. Gutierrez-Lugo MT, Deschamps JD, Holman TR, Suarez E, Timmermann BN. Lipoxygenase inhibition by anadanthoflavone, a new flavonoid from the aerial parts of Anadenanthera colubrina. Planta Med. 2004; $70: 263-5$.

52. Melo JG, De Sousa Araújo TA, De Almeida Castro VTN, De Vasconcelos Cabral DL, Do Desterro Rodrigues M, Do Nascimento SC, et al. Antiproliferative activity, antioxidant capacity and tannin content in plants of semi-arid northeastern Brazil. Molecules. 2010;15:8534-42. 
53. Damascena NP, Souza MTS, Almeida AF, Cunha RS, Damascena NP, Curvello RL, et al. Antioxidant and orofacial anti-nociceptive activities of the stem bark aqueous extract of Anadenanthera colubrina (Velloso) Brenan (Fabaceae). Nat Prod Res. 2014;28:753-6.

54. Ezeabara CA, Okonkwo and E. Comparison of phytochemical and proximate components of leaf, stem and root of Croton hirtus L'Herit and Croton lobatus Linn. Comparison of phytochemical and proximate components of leaf, stem and root of Croton hirtus L'Herit and Croton lobatus Linn.:2 I. 2016.

55. Trentin DDS, Giordani RB, Zimmer KR, Da Silva AG, Da Silva MV, Correia MTDS, et al. Potential of medicinal plants from the Brazilian semi-arid region (Caatinga) against Staphylococcus epidermidis planktonic and biofilm lifestyles. J Ethnopharmacol. 2011;137:327-35.

56. Gois RWDS, Sousa LMD, Lemos TLG, Arriaga AMC, Andrade-Neto M, Santiago GMP, et al. Chemical composition and larvicidal effects of essential oil from bauhinia acuruana (Moric) against Aedes aegypti. J Essent Oil Res. 2011;23:59-62.

57. Ushie OA, Adamu HM, Ogar DA, Gunda HJ. International Journal of Traditional and Natural Medicines, 2013, 2(2): 97-103 International Journal of Traditional and Natural Medicines Phytochemistry of Borreria verticillata Stem Bark. 2013.

58. Baldé AM, Pieters LA, Gergely A, Wray V, Claeys M, Vlietinck AJ. Spermacoceine, a bis-indole alkaloid from Borreria verticillata. Phytochemistry. 1991;30:997-1000.

59. Moreira VF, Oliveira RR, Mathias L, Braz-Filho R, Vieira IJC. New chemical constituents from Borreria verticillata (Rubiaceae). Helv Chim Acta. 2010;93:1751-7.

60. Cavalcanti Clementino EL, Silva Santos J, Felismino D de C, Dantas de Medeiros AC, Silva H, Pereira Chaves T. Evaluation of the biological activity of extracts from commiphora leptophloeos (Mart.) J. B. gillet. Rev Cuba Plantas Med. 2016;21.

61. Santos AO, Ueda-Nakamura T, Dias Filho BP, Veiga Junior VF, Pinto AC, Nakamura CV. Effect of Brazilian copaiba oils on Leishmania amazonensis. J Ethnopharmacol. 2008;120:204-8.

62. Geetha TS, Geetha N. Phytochemical screening, quantitative analysis of primary and secondary metabolites of Cymbopogan citratus (DC) stapf. Leaves from Kodaikanal hills, Tamilnadu. Int $\mathrm{J}$ PharmTech Res. 2014;6:521-9.

63. Shah G, Shri R, Panchal V, Sharma N, Singh B, Mann AS. Scientific basis for the therapeutic use of Cymbopogon citratus, stapf (Lemon grass). Journal of Advanced Pharmaceutical Technology and Research. 2011;2:3-8.

64. Cheel J, Theoduloz C, Rodríguez J, Schmeda-Hirschmann G. Free radical scavengers and antioxidants from lemongrass (Cymbopogon citratus (DC.) Stapf.). J Agric Food Chem. 2005;53:2511-7.

65. Loufoua BAE, Bassoueka DJ, Nsonde Ntandou GF, Nzonzi J, Etou-Ossibi AW, Ouamba JM, et al. Étude ethnobotanique, pharmacologique et phytochimique de quelques plantes médicinales congolaises à potentialité antitussive. Phytothérapie. 2015;13:377-83. 
66. Zohra T, Ovais M, Khalil AT, Qasim M, Ayaz M, Shinwari ZK. Extraction optimization, total phenolic, flavonoid contents, HPLC-DAD analysis and diverse pharmacological evaluations of Dysphania ambrosioides (L.) Mosyakin \& Clemants. Nat Prod Res. 2019;33:136-42.

67. Soares MH, Dias HJ, Vieira TM, de Souza MGM, Cruz AFF, Badoco FR, et al. Chemical Composition, Antibacterial, Schistosomicidal, and Cytotoxic Activities of the Essential Oil of Dysphania ambrosioides (L.) Mosyakin \& Clemants (Chenopodiaceae). Chem Biodivers. 2017;14.

68. Mwanauta RW, Mtei KA, Ndakidemi PA. Prospective Bioactive Compounds from Vernonia amygdalina, Lippia javanica, Dysphania ambrosioides and Tithonia diversifolia in Controlling Legume Insect Pests. Agric Sci. 2014;05:1129-39.

69. Barbosa PBBM, de Oliveira JM, Chagas JM, Rabelo LMA, de Medeiros GF, Giodani RB, et al. Evaluation of seed extracts from plants found in the Caatinga biome for the control of Aedes aegypti. Parasitol Res. 2014;113:3565-80.

70. Pires TCSP, Dias MI, Calhelha RC, Carvalho AM, Queiroz MJRP, Barros L, et al. Bioactive properties of tabebuia impetiginosa-based phytopreparations and phytoformulations: A comparison between extracts and dietary supplements. Molecules. 2015;20:22863-71.

71. Bezerra DAC, Rodrigues FFG, da Costa JGM, Pereira AV, de Sousa EO, Rodrigues EG. Phytochemical approach, bromatologic composition and antibacterial activity of Mimosa tenuiflora (Wild) Poiret and Piptadenia stipulacea (Benth) Ducke. Acta Sci - Biol Sci. 2011;33:99-106.

72. Cecílio AB, Faria DB De, Oliveira PDC, Caldas S, Oliveira DA De, Sobral MEG, et al. Screening of Brazilian medicinal plants for antiviral activity against rotavirus. J Ethnopharmacol. 2012;141:97581.

73. Aleixo ÁA, Vidyleison NC, Karina MSH, Michelli dos S, Rafaella SC, Luciana AR dos SL, et al. Synergistic activity from Hymenaea courbaril L. and Stryphnodendron adstringens (Mart.) Coville against multidrug-resistant bacteria strains. J Med Plants Res. 2015;9:741-8.

74. Félix-Silva J, Gomes JAS, Fernandes JM, Moura AKC, Menezes YAS, Santos ECG, et al. Comparison of two Jatropha species (Euphorbiaceae) used popularly to treat snakebites in Northeastern Brazil: Chemical profile, inhibitory activity against Bothrops erythromelas venom and antibacterial activity. J Ethnopharmacol. 2018;213:12-20.

75. Comandolli-Wyrepkowski CD, Jensen BB, Grafova I, dos Santos PA, Barros AMC, Soares FV, et al. Atividade anti-leishmania de extratos de Libidibia ferrea: Desenvolvimento de testes in vitro e in vivo. Acta Amaz. 2017:47:331-40.

76. Pinto C da P, Rodrigues VD, Pinto F da P, Pinto R da P, Uetanabaro APT, Pinheiro CSR, et al. Antimicrobial Activity of Lippia Species from the Brazilian Semiarid Region Traditionally Used as Antiseptic and Anti-Infective Agents. Evidence-Based Complement Altern Med. 2013;2013:1-5.

77. Ramkissoon JS, Mahomoodally MF, Subratty AH, Ahmed N. Inhibition of glucose- and fructosemediated protein glycation by infusions and ethanolic extracts of ten culinary herbs and spices. Asian Pac J Trop Biomed. 2016;6:492-500. 
78. Zheljazkov VD, Astatkie T. Distillation waste water can modify peppermint (Mentha xpiperita L.) oil composition. Ind Crops Prod. 2012;36:420-6.

79. Kpadonou-Kpoviessi BGH, Kpoviessi DSS, Yayi-Ladekan E, Gbaguidi F, Yehouenou B, Mansourou M, et al. Phytochemical screening, antimicrobial activities and toxicity against Artemia salina Leach of extracts and fractions of Ocimum gratissimum Linn from Benin. J Chem Pharm Res. 2013;5:369-76.

80. Aba PE, Udechukwu IR. Comparative hypoglycemic potentials and phytochemical profiles of 12 common leafy culinary vegetables consumed in Nsukka, Southeastern Nigeria. J Basic Clin Physiol Pharmacol. 2018;29:313-20.

81. Albuquerque Siebra AL, Santiago Lemos IC, de Araújo Delmondes G, Rolim de Oliveira L, Oliveira Brito Pereira Bezerra Martins A, de Carvalho Siebra D, et al. Antimicrobial activity and phytochemical characterization of hydroalcoholic extracts of Passiflora cincinnata mast. (maracujá-do-mato). Rev Cuba Plantas Med. 2014;19:319-28.

82. Patil AS, Paikrao HM. Bioassay guided phytometabolites extraction for screening of potent antimicrobials in Passiflora foetida L. J Appl Pharm Sci. 2012;2:137-42.

83. Xu M, Zha ZJ, Qin XL, Zhang XL, Yang CR, Zhang YJ. Phenolic antioxidants from the whole plant of Phyllanthus urinaria. Chem Biodivers. 2007;4:2246-52.

84. Chung CY, Liu CH, Burnouf T, Wang GH, Chang SP, Jassey A, et al. Activity-based and fraction-guided analysis of Phyllanthus urinaria identifies loliolide as a potent inhibitor of hepatitis $C$ virus entry. Antiviral Res. 2016;130:58-68.

85. Chavasco JM, Prado E Feliphe BHM, Cerdeira CD, Leandro FD, Coelho LFL, da Silva JJ, et al. Avaliação das atividades antimicrobiana e citotóxica de extratos de plantas do cerrado do Sul de Minas Gerais. Rev Inst Med Trop Sao Paulo. 2014;56:13-20.

86. Oliveira LA de, Souza-Moreira TM de, Cefali LC, Chiari BG, Corrêa MA, Isaac VLB, et al. Design of antiseptic formulations containing extract of Plinia cauliflora. Brazilian J Pharm Sci. 2011;47:52533.

87. Morais-Braga MFB, Sales DL, Carneiro JNP, Machado AJT, dos Santos ATL, de Freitas MA, et al. Psidium guajava L. and Psidium brownianum Mart ex DC.: Chemical composition and anti Candida effect in association with fluconazole. Microb Pathog. 2016;95:200-7.

88. González, A. Ramírez, M. Sánchez N. Estudio fitoquímico y actividad antibacterial de Psidium guineense Sw (choba) frente a Streptococcus mutans, agente causal de caries dentales. Rev Cuba Plant Med. 2005;10:11.

89. Rajeswari A. Evaluation of phytochemical constituents, quantitative analysis and antimicrobial efficacy of potential herbs against selected microbes. Asian J Pharm Clin Res. 2015;8:232-7.

90. Calín-Sánchez Á, Martínez JJ, Vázquez-Araújo L, Burló F, Melgarejo P, Carbonell-Barrachina ÁA. Volatile composition and sensory quality of Spanish pomegranates (Punica granatum L.). J Sci Food Agric. 2011;91:586-92.

91. Btissam R, Fatima EM, Kamal E, Hassane G, Mohamed N. Composition and antibacterial activity of hydro-alcohol and aqueous extracts obtained from the lamiaceae family. Pharmacogn $\mathrm{J}$. 
2018;10:81-91.

92. Pérez-Mendoza MB, Llorens-Escobar L, Vanegas-Espinoza PE, Cifuentes A, Ibáñez E, Villar-Martínez AA Del. Chemical characterization of leaves and calli extracts of Rosmarinus officinalis by UHPLCMS. Electrophoresis. 2020;41:1776-83.

93. Amabye TG. Phytochemical Screening and Evaluation of Antibacterial Activity of Ruta graveolens L. A Medicinal Plant Grown around Mekelle, Tigray, Ethiopia. Nat Prod Chem Res. 2015;03:195.

94. Sampaio OM, Vieira LCC, Bellete BS, King-Diaz B, Lotina-Hennsen B, Da Silva MFDGF, et al. Evaluation of alkaloids isolated from Ruta graveolens as photosynthesis inhibitors. Molecules. 2018;23.

95. Akhtar N, Ihsan-ul-Haq, Mirza B. Phytochemical analysis and comprehensive evaluation of antimicrobial and antioxidant properties of 61 medicinal plant species. Arab J Chem. 2018;11:122335.

96. Lima-Saraiva SRG de, Oliveira FG da S, Junior RG de O, Araújo C de S, Oliveira AP de, Pacheco AGM, et al. Chemical Analysis and Evaluation of Antioxidant, Antimicrobial, and Photoprotective Activities of Schinopsis brasiliensis Engl. (Anacardiaceae). Sci World J. 2017;2017:1-10.

97. Abdul-Hafeez E, Ibrahim O, Mahmoud A. Effect of Schinus molle and Schinus terebinthifolius Extracts on Sweet Pea Damping-off. Assiut J Agric Sci. 2016;47:63-74.

98. Lôbo KM., Athayde AC., Silva AM., Rodrigues FF., Lôbo I., Bezerra DA., et al. Avaliação da atividade antibacteriana e prospecção fitoquímica de Solanum paniculatum Lam. e Operculina hamiltonii (G. Don) D. F. Austin \& Staples, do semi-árido paraibano. Rev Bras Plantas Med. 2010;12:227-35.

99. Tripathi AK, Kohli S. Pharmacognostical standardization and antidiabetic activity of Syzygium cumini (Linn.) barks (Myrtaceae) on streptozotocin-induced diabetic rats. J Complement Integr Med. 2014;11.

100. Camelo SRP, Costa RS, Ribeiro-Costa RM, Barbosa WLR, Vasconcelos F, Vieira JW dos S. Phytochemical evaluation and antimicrobial activity of ethanolic extract of Vismia guianensis (Aubl.) choisy. Int J Pharm Sci Res. 2011;2:3224-9.

101. Gaichu DM, Mawia AM, Gitonga GM, Ngugi MP, Mburu DN. Phytochemical screening and antipyretic activities of dichloromethane-methanolic leaf and stem bark extracts of Ximenia americana in rat models. J HerbMed Pharmacol. 2017;6:107-13.

102. Aragão TP, dos Prazeres LDKT, Brito SA, Neto PJR, Rolim LA, da Silva Almeida JRG, et al. Contribution of secondary metabolites to the gastroprotective effect of aqueous extract of ximenia americana $L$. (Olacaceae) stem bark in rats. Molecules. 2018;23.

103. Brito SMO, Coutinho HDM, Talvani A, Coronel C, Barbosa AGR, Vega C, et al. Analysis of bioactivities and chemical composition of Ziziphus joazeiro Mart. using HPLC-DAD. Food Chem. 2015;186:18591.

104. Andrade JC, da Silva ARP, Audilene Freitas M, de Azevedo Ramos B, Sampaio Freitas T, de Assis G. dos Santos F, et al. Control of bacterial and fungal biofilms by natural products of Ziziphus joazeiro Mart. (Rhamnaceae). Comp Immunol Microbiol Infect Dis. 2019;65:226-33. 
105. Albuquerque U, Soldati G, Ramos M, Melo J, Medeiros P, Nascimento A, et al. The Influence of the Environment on Natural Resource Use: Evidence of Apparency. In: Albuquerque UP, De Medeiros PM, Casas A, editors. Evolutionary Ethnobiology. Springer International Publishing; 2015. p. 131-48.

106. Feeny P. Plant Apparency and Chemical Defense. In: Biochemical Interaction Between Plants and Insects. Springer, Boston, MA; 1976. p. 1-40.

107. Stepp JR. The role of weeds as sources of pharmaceuticals. J Ethnopharmacol. 2004;92:163-6.

108. Gobbo-Neto L, Lopes NP. Plantas medicinais: Fatores de influência no conteúdo de metabólitos secundários. Quimica Nova. 2007;30:374-81.

109. Almeida CFCBR, De Lima E Silva TC, De Amorim ELC, Maia MBDS, De Albuquerque UP. Life strategy and chemical composition as predictors of the selection of medicinal plants from the caatinga (Northeast Brazil). J Arid Environ. 2005;62:127-42.

110. Almeida CDFCBR, Cavalcanti De Amorim EL, De Albuquerque UP. Insights into the search for new drugs from traditional knowledge: An ethnobotanical and chemical-ecological perspective. Pharm Biol. 2011;49:864-73.

111. Alencar NL, Araújo TA de S, de Amorim ELC, de Albuquerque UP. Can the apparency hypothesis explain the selection of medicinal plants in an area of caatinga vegetation? A chemical perspective. Acta Bot Brasilica. 2009;23:910-1.

112. Albuquerque UP de. Implications of Ethnobotanical Studies on Bioprospecting Strategies of New Drugs in Semi-Arid Regions. Open Complement Med J. 2010;2:21-3.

113. Firn R. Nature's Chemicals. Oxford University Press; 2009.

114. Moerman DE. Society for the Anthropology of Consciousness Distinguished Lecture: Consciousness, "Symbolic Healing," and the Meaning Response. Anthropol Conscious. 2012;23:192-210.

115. Moerman DE, Jonas WB. Deconstructing the Placebo Effect and Finding the Meaning Response. Ann Intern Med. 2002;136:471.

116. Watson A, Power A, Brown C, El-Deredy W, Jones A. Placebo analgesia: Cognitive influences on therapeutic outcome. Arthritis Research and Therapy. 2012;14:1-7.

\section{Tables}

Due to technical limitations, Table 3 is only available as a download in the Supplemental Files section.

\section{Supplementary Files}

This is a list of supplementary files associated with this preprint. Click to download.

- Table3.docx 